\title{
Research progress on Toll-like receptor signal transduction and its roles in antimicrobial immune responses
}

\author{
Pengpeng Xia ${ }^{1,2,3}$ (D) Y Yunping Wu ${ }^{1,2,3} \cdot$ Siqi Lian ${ }^{1,2,3} \cdot$ Li Yan ${ }^{1,2,3} \cdot$ Xia Meng ${ }^{1,2,3} \cdot$ Qiangde Duan ${ }^{1,2,3}$. \\ Guoqiang Zhu ${ }^{1,2,3}$
}

Received: 25 February 2021 / Revised: 7 May 2021 / Accepted: 8 June 2021 / Published online: 28 June 2021

(C) The Author(s), under exclusive licence to Springer-Verlag GmbH Germany, part of Springer Nature 2021

\begin{abstract}
When microorganisms invade a host, the innate immune system first recognizes the pathogen-associated molecular patterns of these microorganisms through pattern recognition receptors (PRRs). Toll-like receptors (TLRs) are known transmembrane PRRs existing in both invertebrates and vertebrates. Upon ligand recognition, TLRs initiate a cascade of signaling events; promote the pro-inflammatory cytokine, type I interferon, and chemokine expression; and play an essential role in the modulation of the host's innate and adaptive immunity. Therefore, it is of great significance to improve our understanding of antimicrobial immune responses by studying the role of TLRs and their signal molecules in the host's defense against invading microbes. This paper aims to summarize the specificity of TLRs in recognition of conserved microbial components, such as lipoprotein, lipopolysaccharide, flagella, endosomal nucleic acids, and other bioactive metabolites derived from microbes. This set of interactions helps to elucidate the immunomodulatory effect of TLRs and the signal transduction changes involved in the infectious process and provide a novel therapeutic strategy to combat microbial infections.
\end{abstract}

\section{Key points}

- TLRs exert an immediate and direct defense against invading microbes.

- Microbial components and metabolites are crucial for the activation of the host immune responses.

- TLRs provide beneficial immunomodulatory properties to the host.

Keywords Toll-like receptors $\cdot$ Microorganism $\cdot$ Anti-infective immunity $\cdot$ Signal transduction

\section{Introduction}

Pathogens, or microscopic organisms, that invade a host and lead to an infection, including bacteria, viruses, and fungi, endanger human or animal health and hinder economic development. Due to their high infectivity and mortality rate, some microbes contribute to major public health issues, such as the 2019-nCoV (Malik et al. 2020), Ebola virus (Nanziri et al.
Pengpeng Xia

ppxia@yzu.edu.cn

Guoqiang Zhu

yzgqzhu@yzu.edu.cn

Yunping $\mathrm{Wu}$

mx120190734@yzu.edu.cn

Siqi Lian

1435946956@qq.com

Li Yan

yanli3559@163.com

Xia Meng

mengxia_1@126.com
Qiangde Duan

dqd@yzu.edu.cn

1 College of Veterinary Medicine (Institute of Comparative Medicine), Yangzhou University, 12th East Wenhui Road, Yangzhou 225009, China

2 Jiangsu Co-innovation Center for Prevention and Control of Important Animal Infectious Diseases and Zoonoses, Yangzhou 225009, China

3 Joint International Research Laboratory of Agriculture and Agri-Product Safety of Ministry of Education of China, Yangzhou University, Yangzhou 225009, China 


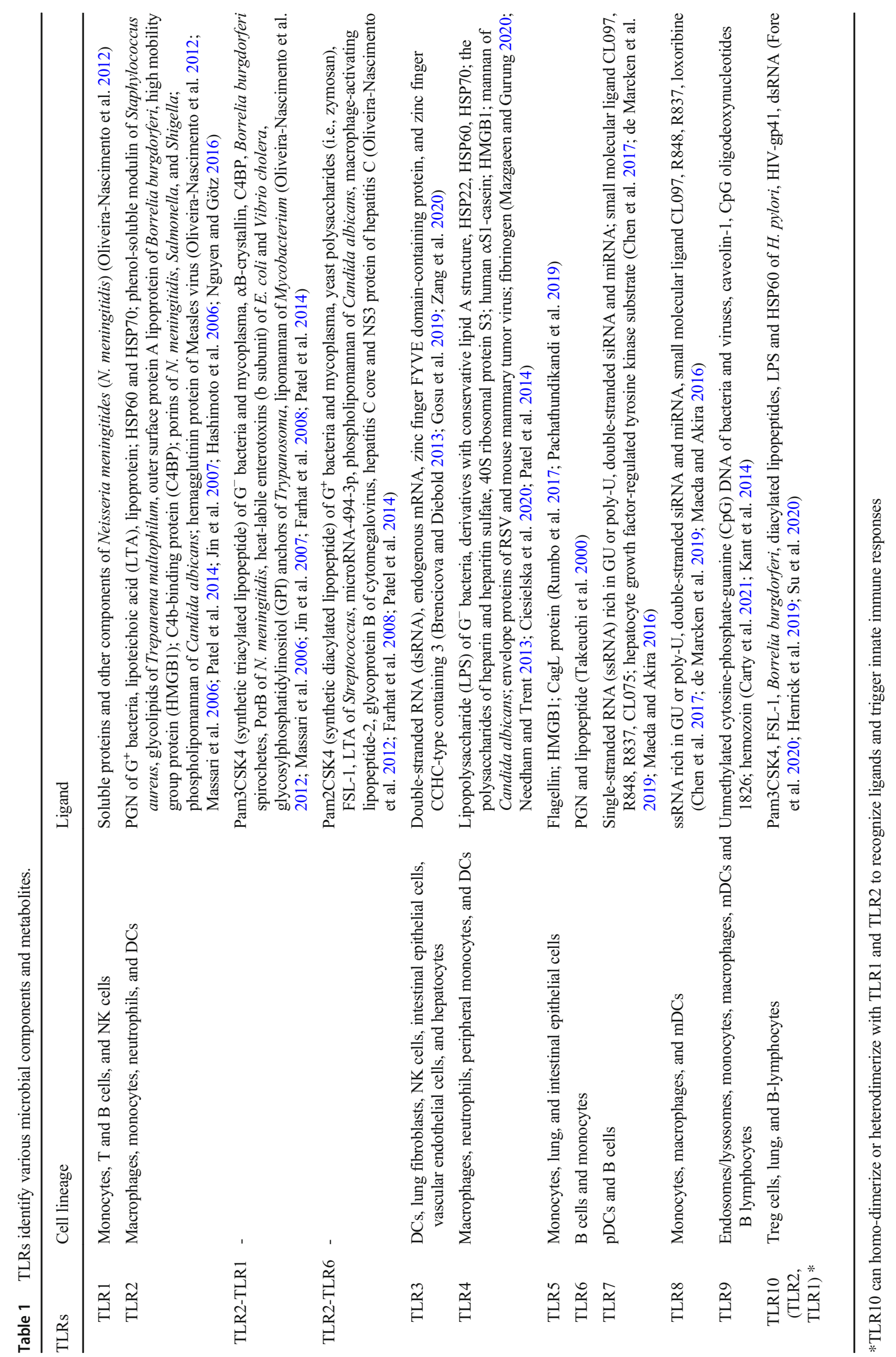


2020), highly pathogenic avian influenza (Tasiame et al. 2020), and antibiotic-resistant superbugs (Wang et al. 2019). In addition to the microbes themselves, microbial metabolites and components also affect host health, including flagella, lipopolysaccharide (LPS), short-chain fatty acids (SCFAs), bile acids, and lactic acid (Kayama et al. 2020), among others.

To resist microbial invasion, hosts have gradually developed a variety of mechanisms to survive during the process of long-term evolution. The innate immune response induced by pattern recognition receptor (PRRs) with recognition of pathogen-associated molecule patterns (PAMPs) plays a vital role in a host's defense against pathogenic microbial infection. PRRs are mainly composed of Toll-like receptors (TLRs), Ctype lectin receptors, cytoplasmic DNA sensors (i.e., cyclic GMP-AMP synthase), and several other cytoplasmic receptors, such as RIG-I-like receptors (RLRs) or Nod-like receptors (NLRs) (Cai et al. 2019; Bhattarai et al. 2018). Among them, TLRs were the first to be discovered and one of the most extensively studied PRRs. They are present in many species, including 10 functional members in humans (TLR1-TLR10) and 12 in mice (TLR1-TLR9 and TLR11-TLR13) (Akira et al. 2006). According to their amino acids and genomic structure, these mammalian TLRs can be divided into five significant subfamilies. For example, TLR2, together with TLR1, TLR6, and TLR10, forms the TLR2 subfamily (Farhat et al. 2008). The TLR9 subfamily consists of TLR7, TLR8, and TLR9 (Wagner 2004).

All TLRs are type I transmembrane proteins composed of an extracellular domain (ECD), a transmembrane domain (TM), a cytoplasmic domain (CP), and a single transmembrane helix that connects the ECD and CP. The $\mathrm{CP}$ often has a highly conserved Toll/IL-1 receptor domain (TIR) and polymerizes to recruit downstream adaptors, such as myeloid differentiation primary response 88 (MyD88) and TIRdomain-containing adapter-inducing interferon- $\beta$ (TRIF), to activate nuclear factor kappa-B (NF- $\mathrm{KB}$ )-dependent and interferon regulatory factor (IRF)-dependent signaling pathways, and induces the production of inflammatory cytokines and type I interferons (IFNs) (Bowie and O'Neill 2000; Balka and De Nardo 2019). According to the number and structure of Leucine-rich repeats (LRRs) in an ECD, different TLRs can recognize their specific ligands and exert the corresponding immunological functions through various ways in response to signals (Yin et al. 2015). This review will summarize the role of TLRs and their unique signal molecules in microbial infections to highlight the function of TLRs and provide new strategies and ideas for the prevention and treatment of microbial infectious diseases.

Recent studies have shown that TLRs can recognize microorganisms and their non-specific and conserved components and metabolites after an infection (Table 1) (Akira et al. 2006; Levy et al. 2017; Oliveira-Nascimento et al. 2012; Patel et al. 2014). Subsequently, the interaction between
TLRs and microorganisms initiates the innate immune response, inducing the expression of interleukin 6 (IL-6), IL-8, IL-12, and tumor necrosis factor (TNF)- $\alpha$ by activated mitogen-activated protein kinase (MAPK) and downstream NF-KB signal pathways (Kawai and Akira 2007; Mukherjee et al. 2016). Expression of these cytokines results in chemotaxis and aggregation of granulocytes and macrophages, leading to an inflammatory reaction and immune response. Simultaneously, the interaction between microorganisms and the host's immune system also determines the fate of microorganisms in the body (Netea et al. 2004a; Netea et al. 2004b). In the following sections, we will discuss how TLRs recognize the corresponding microbial components or metabolites and their roles in the immune response against microbial infection.

\section{Lipoprotein is the predominant ligand for the TLR2 subfamily}

Lipoprotein is a cell membrane anchor protein that widely exists in Gram-negative $\left(\mathrm{G}^{-}\right)$and Gram-positive $\left(\mathrm{G}^{+}\right)$bacteria. In $\mathrm{G}^{+}$bacteria, lipoproteins with low guanine and cytosine (GC) content mainly exist in the form of diacylated lipoproteins. In contrast, those in $\mathrm{G}^{-}$and $\mathrm{G}^{+}$bacteria with a high $\mathrm{GC}$ content mainly exist in the form of triacylated lipoproteins (Braun and Hantke 2019). As reported, bacterial lipoproteins play an important role in adhesion, protein secretion, signal transduction, cell wall metabolism, biofilm formation, and innate immune response, especially in triggering innate and adaptive immunity through TLRs (Braun and Hantke 2019; Nguyen and Götz 2016). Understanding the interaction of lipoproteins with TLRs, especially with the TLR2 subfamily, will facilitate the study of the potential of lipoproteins as candidate vaccines and drug targets for infectious diseases caused by related bacteria (Hashimoto et al. 2006; Nguyen and Götz 2016).

Mycobacterium tuberculosis (Mtb) is a great target to study the role of bacterial lipoproteins because it has various kinds of lipoproteins, including lipoarabinomannan (LAM), mannose-capped LAM, $19 \mathrm{kDa}$ lipoprotein (LpqH), phosphatidylinositol mannoside, lipoprotein (Lpr) G, LprA, LpqB, and LpqM (Sutcliffe and Harrington 2004). Most of them interact with TLR2 and participate in the innate immune response of a host against $\mathrm{Mtb}$. $\mathrm{LpqH}$ activates autophagy in a TLR2-dependent manner, resulting in IL-15 and IL-1 $\beta$ expression, and an increase in the antimicrobial activity of monocytes towards Mtb (Shin et al. 2010). However, the combination of $\mathrm{LpqH}$ and TLR2 can also inhibit the expression of IFN- $\gamma$. Upon this, IFN- $\gamma$-induced expression of class II transactivators is diminished, and a decrease of IFN- $\gamma$-induced class II major histocompatibility complex (MHC) genes in macrophages further leads to bacteria escaping the host's 
defense system and allows the colonization of bacteria in the body (Braun and Hantke 2019; Padhi et al. 2019; Pennini et al. 2006). Besides, LprE can inhibit the expression of the cathelicidin antimicrobial peptide, IL-1 $\beta$, IL-12, and IL-22 by the TLR2-p38-CYP27B1VDR signal pathway to promote intracellular bacterial survival (Padhi et al. 2019). Another lipoprotein from Mtb, LprG, inhibits the antigen presentation of MHC class II molecules in human macrophages and is beneficial to localize LAM on the cell surface to inhibit the fusion of phagosomes and lysosomes (Braun and Hantke 2019; Sutcliffe and Harrington 2004). All these activities can help Mtb escape from the host's immune response and promote the survival and reproduction of bacteria in a host. Thus, TLRs seem likely to play dual roles in the process of pathogenic microbial infection. They can enhance the body's immune response and resist pathogenic microbial infection as well as help microorganisms escape immune system clearance (Netea et al. 2004b).

In addition to TLR2, lipoproteins and lipoprotein-derived lipopeptides also bind to TLR2-TLR1 and TLR2-TLR6 heterodimers (Braun and Hantke 2019). In the TLR2-TLR1 heterodimer, there is a gap in the protruding region between the central part and the C-terminal region of TLR2, where two lipid chains in the triacylated lipopeptide are inserted into TLR2, and another lipid chain binds to the lipid-binding channel between the central and the C-terminal regions of TLR1 (Jin et al. 2007). The structures of TLR6 and TLR1 are highly homologous, but TLR6 lacks lipid-binding channels, and the acylated degree of lipoproteins distinguishes the interaction of TLR2 with TLR1 and TLR6, resulting in their different performances in identifying and scavenging microorganisms (Oliveira-Nascimento et al. 2012; Triantafilou et al. 2006). For example, TLR1-TLR2 mainly recognizes triacylated lipopeptide in microorganisms and their components, such as Mtb, Borrelia burgdorferi spirochetes, and Leishmania, whereas TLR2-TLR6 recognizes the diacylated lipopeptides of respiratory syncytial virus (RSV), hepatitis $\mathrm{C}$ virus (HCV), herpes simplex virus (HSV-1 and HSV-2), among others (Oliveira-Nascimento et al. 2012; Patel et al. 2014).

Although TLR1 and TLR6 are generally considered to exert their biological function through the formation of heterodimers with TLR2, they still play roles in the process of microbial infections individually (Braun and Hantke 2019; Raieli et al. 2019). TLR1 activation enhances the specific immune response by promoting co-stimulatory molecule expression, pro-inflammatory cytokine secretion, and the proliferation and polarization of Th cells. In contrast, TLR2 activation mainly induces the expression of IFN, which has a wide range of functions in innate immunity (Raieli et al. 2019). Studies have shown that Pam3CSK4, a synthetic triacylated lipopeptide, can be recognized by TLR1-TLR2 and can induce the activation and maturation of dendritic cells (DCs), but blocking TLR1 and TLR2 on plasmacytoid dendritic cells
(pDCs) has different effects on the cytokine-induced secretion of helper T cells (Th). The blockage of TLR1 on pDCs can reduce the polarization of regulatory $\mathrm{T}$ cells (Tregs) but does not affect Th1 cells, while blocking TLR2 can specifically inhibit the secretion of IFN without affecting $T$ cell polarization (Oliveira-Nascimento et al. 2012; Raieli et al. 2019). In dextran sulfate sodium salt (DSS)-induced ulcerative colitis (UC) co-infected with Candida albicans (Candin, Sc5314), the deletion of TLR1 can aggravate intestinal inflammation, leading to colon injury and mouse death. In contrast, the deletion of TLR6 can promote the elimination of Candin. Results based on cytokine detection also indicate that TLR1 deletion can significantly upregulate the expression of TNF- $\alpha$, IL- $1 \beta$, and IL-17A, while the deletion of TLR6 downregulates the expression of these cytokines (Choteau et al. 2017). In TLR6-deficient mice, the expression of the Th2-derived anti-inflammatory cytokine IL-10 decreased, and the release of the Th1-derived pro-inflammatory cytokine IFN- $\gamma$ increased. Therefore, TLR1 can inhibit the expression of cytokines and prevent tissue damage caused by an inappropriate immune reaction. At the same time, TLR6 can regulate the balance between $\mathrm{Th} 1$ and $\mathrm{Th} 2$ cytokines after recognizing Candin and eliminates its infection by enhancing inflammatory responses (Choteau et al. 2017; Triantafilou et al. 2006).

To our knowledge, TLR10, another member of the TLR2 subfamily, has high structural homology with TLR1 and TLR6. It can homo-dimerize or heterodimerize with TLR1 and TLR2 (Fore et al. 2020; Xiang et al. 2020). Nevertheless, the research on the ligand recognition, signal pathway, and biological function of TLR10 is not comprehensive yet. Some studies have shown that ligands interacting with TLR2 are also considered as the ligands of TLR10, including Pam2CGDPKHPKSF (FSL-1), a synthetic diacylated lipoprotein that activates the TLR2/TLR6 heterodimer and lipopeptide Pam3CSK4 (Fore et al. 2020). Furthermore, TLR10 may heterodimerize with TLR2 to recognize LPS and heat shock proteins (HSP60) of Helicobacter pylori (H. pylori) to trigger innate immune responses. PamCysPamSK4, a diacylated peptide, could be recognized by the TLR10 homodimer and TLR1/TLR10 heterodimer (Fore et al. 2020; Su et al. 2020). A recent study has shown that TLR10 can enhance gp41-mediated IL-8 induction and NF- $\mathrm{KB} \alpha$ activation and modulate HIV-1 infection and integration independent of TLR2 (Henrick et al. 2019). Moreover, TLR10 can upregulate chemokine ligand 20 and IL-8 expression in response to Listeria monocytogenes (EGD) and Salmonella typhimurium (S. typhimurium) infections, while the infection with $\mathrm{H} 1 \mathrm{~N} 1(\mathrm{~A} / \mathrm{HK} / 54 / 98)$ and $\mathrm{H} 5 \mathrm{~N} 1$ (A/Vietnam/3212/04) influenza virus leads to an increased TLR10 expression and triggers the induction of proinflammatory cytokines and interferons in the host (Latorre et al. 2016; Lee et al. 2014a, 2014b; Regan et al. 2013). TLR10 is the only TLR that can antagonize TLR2 activity, 
inhibit downstream signal transductions, and suppress B cell adaptive immune responses (Hess et al. 2017; Oosting et al. 2014; Su et al. 2020). It acts as a negative regulator of both MyD88 and TRIF-mediated signaling, suppressing the degradation of IkB and the phosphorylation of MAPKs through the production of IFN- $\beta$ (Jiang et al. 2016). In addition, TLR10 is associated with a decreased risk of diseases, such as Pneumococcal meningitis in children and prostatitis, and can affect the morphology of adipose tissue in obese patients (Fan et al. 2019; Fore et al. 2020; Xiang et al. 2020).

\section{LPS is mostly recognized by TLR4 and triggers the host inflammatory response}

LPS is an endotoxin that exists as a major constituent of the outer membrane of $\mathrm{G}^{-}$bacteria and is essential to maintain the integrity and viability of bacteria (Rietschel et al. 1994). After exposure to human blood, LPS has substantial toxicity and mainly causes fever, leukocyte changes, respiratory diseases, and even sepsis (Basauri et al. 2020). During this process, the body first recognizes LPS through the corresponding receptors, such as TLR4, and then initiates the body's defense mechanism to affect LPS clearance. Meanwhile, the prolonged acute exposure to LPS drives LPS tolerance and triggers immunosuppression in the body, which in turn causes organ dysfunction and damage (Basauri et al. 2020; Langston et al. 2019). In this regard, broadening our understanding of the recognition and removal of LPS may contribute significantly to the understanding of a host's defense against bacterial infections.

As is well known, LPS is composed of lipid A, a core oligosaccharide, and O-antigen. These components can induce effective immune responses and are responsible for bacteria escaping from the host's immune system (Mazgaeen and Gurung 2020; Rietschel et al. 1994). Although LPS is well conserved among $\mathrm{G}^{-}$bacteria, the lipid A moiety is widely varied in different bacteria through numerous lipid A modifications. The diversity of lipid A alterations leads to a different immune-stimulatory capacity of LPS and affects the pathogenesis of many bacteria, including S. Typhimurium, H. pylori, Francisella tularensis (Ft), and Vibrio cholera (Mazgaeen and Gurung 2020; Needham and Trent 2013). Among them, the LPS of pathogenic Escherichia coli (E. coli) and S. typhimurium that comprise the hexa-acylated lipid A structure stimulated a strong TLR4-dependent inflammatory response in the host. The tetra-acylated lipid A of Yersinia pestis ( $Y$. pestis) growing at $37{ }^{\circ} \mathrm{C}$ and a tetraacylated lipid A mutant in the Ft subspecies novicida (U112) lack immune-stimulatory activity, thus enabling bacteria to evade immune recognition and survive within a host (Li et al. 2012; Needham and Trent 2013). Additionally, some pathogens synthesize a hexa-acylated form of lipid A, representing an antagonistic effect on TLR4, which induces the transient receptor potential channels or caspase-11 (caspase- 4 and -5 ) activation to initiate non-canonical inflammasome independent of TLR4, such as Legionella pneumophila, Citrobacter rodentium, Shigella flexneri, and Burkholderia spp. (Ciesielska et al. 2020; Yang et al. 2015; Yi 2017). In addition to lipid A, the intact structure of LPS core oligosaccharides affects innate immunity recognition in some cases. For instance, the LPS core mutant of Brucella abortus displayed an increased detection by TLR4-myeloid differentiation protein (MD)-2. In contrast, the LPS core hampered MD-2 recognition and is essential for Brucella to escape recognition in the early stages of infection (Conde-Álvarez et al. 2012). Besides, the full-length O-antigen of LPS and the lipoproteins that impair the leukocyte differentiation antigen 14 (CD14) binding contribute to the Leptospira interrogans escape from TLR4 internalization and avoid TLR4/TRIF-dependent antimicrobial responses (Bonhomme et al. 2020). Thus, TLR4 is the most important receptor for the immunological recognition of LPS.

TLR4 is expressed on the surface of various phagocytes, including macrophages, peripheral monocytes, neutrophils, and DCs. It acts as a cell sensor for extracellular LPS and associates with LPS-binding protein (LBP), MD2, and CD14 to initiate immune responses (Ciesielska et al. 2020; Mazgaeen and Gurung 2020). The duality property of LBP and CD14 states that both of them serve as effect molecules to modulate cellular and systemic responses to LPS. In the early step of bacterial infection, serum LPS mainly binds to the $\mathrm{N}$ terminal of LBP to form the LPS-LBP complex, which aids in LPS recognition by presenting it to CD14 and then accelerates the transfer of LPS to MD-2 or the TLR4/MD-2 complex (Jerala 2007; Kitchens and Thompson 2005; Richter et al. 2012). The formed M-type TLR4/MD-2/LPS dimers further induce the dimerization of TIR domains in cells, initiate CD14-dependent TLR4 endocytosis, and TRIF-dependent signal transduction to promote inflammation caused by LPS (Ciesielska et al. 2020; Rosadini and Kagan 2017). However, during infection and sepsis, the high concentrations of LBP and CD14 can both sequester LPS to prevent exaggerated inflammatory responses by different mechanisms, including transferring LPS to plasma lipoproteins, extracting LPS already bound to CD14, and dampening LPS interaction with TLR4/MD-2 complex (Ciesielska et al. 2020; Gegner et al. 1995; Kitchens and Thompson 2005; Mazgaeen and Gurung 2020; Richter et al. 2012).

In different cells, there are subtle differences in the TLR4dependent recognition of LPS as well. When macrophages were stimulated with $E$. coli or S. typhimurium, the C-type lectin, SIGNR1, could recognize the polysaccharide portion of LPS and enhance the oligomerization of TLR4-MD2 complex to augment the production of pro-inflammatory cytokines without the aid of CD14. Meanwhile, mice lacking SIGNR1 
can resist the infection of LPS and colitis induced by DSS by reducing intestinal injury and the production of proinflammatory cytokines (Mazgaeen and Gurung 2020; Nagaoka et al. 2005). Upon LPS stimulation, integrin CD11b promotes TLR4 endocytosis and TRIF signal transduction in DCs, whereas it inhibits TLR4-dependent immune reaction to LPS by promoting the degradation of TIRAP and MyD88 in macrophages (Ling et al. 2014; Rosadini and Kagan 2017). Notably, TLR4 is also involved in the inflammatory response triggered by other virulence determinants dependent or independent of the conventional LPS/CD14 pathway. For instance, the major and minor fimbriae of Porphyromonas gingivalis require TLR2 and TLR4 to stimulate the immune response, and the participation of MD2 and CD14 facilitates the TLR4 signaling (Davey et al. 2008). P fimbriae of uropathogenic $E$. coli bind to surface glycosphingolipids and recruit TLR4 as co-receptors to stimulate mucosal inflammation in a CD14-independent way (Frendéus et al. 2001). FimH, an adhesion of type 1 fimbriae, binds directly to TLR4 and signals through both MyD88 and TRIF to trigger IRF3 activation to induce an innate antiviral response (Ashkar et al. 2008).

\section{Flagellin is the specific ligand for TLR5 recognition and provides beneficial immunomodulatory property to the host}

Flagellin constitutes flagella conducive to bacterial movement and works as a virulence factor to promote bacteria to adhere to and invade host cells (Duan et al. 2013; Ramos et al. 2004; Yang et al. 2016). The deletion of flic, a gene encoding the major flagellin protein, resulted in abnormal growth and decreased motility and biofilm formation of bacteria, such as Edwardsiella tarda, Cronobacter malonaticus (G361, O:2), and F18 enterotoxigenic E. coli (ETEC) (F107/86, O139:H1:F18ab) (Duan et al. 2012; He et al. 2012; Ling et al. 2021). Previous studies have shown that flagellin also contributes to probiotic effects and has emerged as an immune modulator to affect the interaction between bacteria; these responses were closely associated with the flagellin concentration and the monomer-specific structural features (Duan et al. 2012; Lebeer et al. 2010; Luo et al. 2019; Rossez et al. 2015).

In addition to some commensal bacteria that do not express flagella, such as Bacteroides spp., most commensal and probiotic bacteria were shown to produce flagellin to participate in the modulation of the host's innate and adaptive immune responses (Lebeer et al. 2010). It has been noted that the flagellin of the probiotic $E$. coli Nissle 1917 induced human $\beta$-defensin 2 expression to counteract bacterial adherence and invasion (Schlee et al. 2007). However, the increase in the concentration of flagellin in the intestine caused by infection with flagellated pathogenic bacteria would lead to the destruction of the intestinal mucosa and chronic inflammation (Cullender et al. 2013). Upon stimulation of different sensory pathways, bacterial flagellin triggers various host responses and exhibits effective mucosal adjuvanticity and substantial potential to resist tumor growth and radiation-associated tissue damage (Hajam et al. 2017). The cytoplasmic flagellin can bind with two NLRs, the neuronal apoptosis inhibitor family protein (i.e., Naip-5 and -6) and the ICE proteaseactivating factor (also known as NLRC4), to activate downstream caspase-1 and induce inflammation and apoptosis (Hajam et al. 2017; Miao et al. 2006). TLR5 can recognize extracellular flagellin and utilize MyD88 to initiate MAPK signaling and NF- $\mathrm{KB}$ activation, stimulating cytokine secretion and eliciting an inflammatory response to eliminate pathogens (Hajam et al. 2017; Ramos et al. 2004). For instance, the flagellin of F4 ETEC (C83901, O8:K87: F4ab) induces TLR5-mediated IL-17C expression in intestinal epithelial cells and increases antimicrobial peptides and tight junction protein expression in an autocrine/paracrine manner to promote the mucosal host defense against bacterial infection (Luo et al. 2019). Simultaneously, a low expression of TLR5 will suppress the immune response to ETEC infection and reduce cell damage in the intestine (Dai et al. 2019).

The flagellin monomer is a potent stimulator for TLR5 activation and can be divided into four domains, including the terminal and central $\alpha$-helixes (D0 and D1) and the hypervariable $\beta$-sheets and turns (D2 and D3) (Rumbo et al. 2017). The D0 domain of flagellin contributes to the signal transduction of TLR5 but has no effects, or only a slight one, on TLR5 binding. The D1 domain contains highly conserved regions, which provide the most binding sites for TLR5, and is closely related to signal transduction (Yoon et al. 2012). The shortest flagellin consists of the D0 and D1 domains in Bacillus subtilis (B. subtilis, W23), lacks the hypervariable domains, and still triggers efficient TLR5 recognition and the subsequent signal transduction (Song et al. 2017). R89, L93, and E113 residues in the D1 domain of flagellin are critical to interact with the TLR5 LRR9 loop for inducing IL-6 and IL-8 transcription and TLR5 activation in B. subtilis and Treponema pallidum, whereas R89T and E114D flagellin mutants of Campylobacter jejuni (C. jejuni) and H. pylori failed to bind with TLR5, thus evading immune recognition by TLR5 (Song et al. 2017; Xu et al. 2019). Thus, the D0 and $\mathrm{D} 1$ domains are the minimal regions required for TLR5 activation; even the CagL protein of type IV secretory system from the highly virulent $H$. pylori strain contains a D1-like motif that can activate TLR5 and downstream signal transduction in vitro (Pachathundikandi et al. 2019). 


\section{Recognition of endosomal nucleic acids by TLR3 and TLR9 subfamily is essential to detect and combat pathogens}

Endosomal nucleic acids derived from invading pathogens, such as double-stranded RNA (dsRNA), single-stranded RNA (ssRNA), and DNA sequences rich in unmethylated CpGs motif, are mainly recognized by TLR3, TLR7, TLR8, and TLR9, respectively (Lee and Barton 2014; Wagner 2004). These receptors are localized in the endoplasmic reticulum (ER) and endosome/lysosome of cells and act as sensors to promote stimulatory and nonstimulatory discrimination by various mechanisms (Brencicova and Diebold 2013; Lee and Barton 2014), which may help initiate antimicrobial defenses and devise therapeutic strategies.

TLR3 is a well-known receptor for the viral replication product, dsRNA, and synthetic analog, polyinosinicpolycytidylic acid (poly I:C), and plays an essential role in viral infections (Brencicova and Diebold 2013; Carty et al. 2021). The dynamic structural analysis of the TLR3-dsRNA complex suggests that an acidic $\mathrm{pH}$ and the formation of "M"shaped homodimers are both necessary for TLR3 to bind ligands, and His60, His108, His539, and Asn541 are critical residues to affect the complex formation and TLR3 signaling (Gosu et al. 2019; Liu et al. 2008). TLR3 is widely expressed in many cells, including DCs, natural killer (NK) cells, intestinal epithelial cells, lung fibroblasts, vascular endothelial cells, and hepatocytes (Carty et al. 2021). Upon dsRNA binding, TLR3 recruits the adaptor TRIF to the TIR domain, thereby activating innate immunity and leading to robust induction of IFNs and inflammatory cytokine expression (Bianchi et al. 2020; Carty et al. 2021). Based on this, TLR3 is sufficient to prevent virus replication and to mediate antiviral responses to eliminate pathogens, such as encephalomyocarditis virus (EMCV), poliovirus, dengue virus (DENV), hepatitis B virus (HBV), HCV, and HSV (Carty et al. 2021; Lester and Li 2014). The zinc-finger protein $\mathrm{ZCCHC} 3$ can further positively regulate TLR3-mediated signaling by promoting the recruitment of TRIF to TLR3 after ligand stimulation (Zang et al. 2020). Many viruses have evolved strategies to dampen TRIF effects on TLR3-mediated IFN signaling and promote survival within the host. For example, the HCV-encoded NS4B protein can induce TRIF degradation in a caspase8dependent manner and evade IFN responses (Liang et al. 2018). However, TLR3-mediated inflammatory responses also play a detrimental role in some viral infections. During influenza A virus (IAV) infection, the deficiency of TLR3 in mice prolonged the survival time and improved the outcomes in IAV-induced acute pneumonia (Le Goffic et al. 2006).

In endolysosomal compartments, viral or bacterial ssRNA and nucleoside analogs (i.e., loxoribine) are recognized by TLR7 and TLR8. These two TLRs exist as dimers in the resting state and are converted into an activated state upon ligand binding, and the cleavage of the Z-loop (the horseshoe-like shape structure or the hinge region between LRR14 and LRR15) by proteases and arginine endopeptidases is a prerequisite for their conformation changes and activation (Maeda and Akira 2016; Ohto et al. 2014). Due to their structural similarities, TLR7 and TLR8 can recognize similar ligands, including ssRNA rich in GU or poly-U derived from IAV, vesicular stomatitis virus (VSV), human immunodeficiency virus (HIV), Pseudomonas aeruginosa and E. coli, double-stranded siRNA and miRNA, self-RNAs released from dead or dying cells, and the small molecular ligand CL097 (3M001) and resiquimod (R848) (Chen et al. 2017; Ao et al. 2019; Maeda and Akira 2016).

Crystal structure analysis showed that TLR7 could recognize guanosine $(\mathrm{G})$ and uridine $(\mathrm{U})$ in ssRNA at the same time, but the binding sites are different. Site I recognizes and binds with $\mathrm{G}$ or small molecular ligands to activate TLR7, and a mutation at E583, L528, and R553 can abolish these recognitions. Site II (C98-C475) mainly recognizes U and can enhance the binding ability of site I, but it cannot recognize small molecular ligands (Zhang et al. 2016; Zhang et al. 2018). Similarly, there are double ligand binding sites present in hTLR8. The site I mainly recognizes $U$ or small molecular ligands, and the F405 mutation can abolish these recognitions, whereas D543, Y348, and T574 mutations can weaken the activation of the NF- $\mathrm{KB}$ signal pathway. Site II mainly recognizes $G$ and promotes the binding of site I to ligands by stabilizing the Z-loop structure and enhancing the affinity between site I and the corresponding ligands. Mutation at H373, R375, R429, Y468, F470, and L474 can weaken the recognition of ssRNA by hTLR8 but has no significant effect on the recognition of small molecular ligands (Tanji et al. 2015; Gantier et al. 2010).

TLR7 is mainly expressed by pDCs and B cells, whereas TLR8 expression is restricted to monocytes, macrophages, and myeloid DCs (mDCs) (Carty et al. 2021; Gantier et al. 2010). Even though they share homology in their structures and have similar binding ligands, the activation of TLR7 and TLR8 triggers different signal pathways in the body. It results in different responses to microbial infections. For instance, during human monocyte infection with coxsackievirus, EMCV, IAV, measles virus, Sendai virus, and VSV, TLR7 preferentially promotes the expression of $\mathrm{CD}^{+} \mathrm{Th} 17$ cytokines through the MAPK signaling pathway, while TLR8 promotes Th1 cytokine production and IFN responses through NF-KB signal (Bender et al. 2020; Lawrence 2009; de Marcken et al. 2019). This difference may be due to the activation of TLR7 along with an increase of intracellular $\mathrm{Ca}^{2+}$ concentration and ERK1/2 stimulation, which promotes the expression of FOSL1 and inhibits the production of type I pro-inflammatory cytokines, such as IL-27 and TNF- $\alpha$ (de Marcken et al. 2019). 
Unmethylated $\mathrm{CpG}$ DNA in bacteria and viruses, such as Lactobacillus plantarum (WCFS1), Lactobacillus rhamnosus (GG, ATCC 53103), HSV, and DENV, are the specific ligands to activate TLR9, leading to interferon release and inflammation (Carty et al. 2021; Kant et al. 2014). TLR9, which is mainly expressed in B lymphocytes and $\mathrm{mDCs}$, in a steadystate, is present as a monomer and then forms an " $\mathrm{M}$ "-shaped homodimer upon binding to active DNA sequences (Blaas et al. 2009; Ohto et al. 2015). After TLR9 proteolytic cleavage, the C-terminal cleavage product triggers TLR9-mediated signaling. However, the N-terminal cleavage product promotes the degradation of its $\mathrm{C}$-terminal region in the lysosome or interacts with the $\mathrm{C}$-terminal cleavage product to inhibit the formation of the C-terminal TLR9 fragment homodimers, thereby preventing excessive TLR9 signaling (Lee et al. 2014a, 2014b). Therefore, TLR9 plays an essential role in the modulation of the immune response against microbial infections.

When DENV infects human DCs, mitochondrial DNA (mtDNA) is released into the cytoplasm through reactive oxygen species and inflammasome production. Then, mtDNA upregulates TLR9 expression and activates TLR9 signaling to induce the secretion of the antiviral cytokines IFN- $\beta 1$, IFN- $\lambda 1$, IFN- $\lambda 2$, and IFN- $\lambda 3$ (Lai et al. 2018). In addition to eliciting Th1 immune responses via TLR9, bacterial DNA motifs and synthetic $\mathrm{CpG}$ oligodeoxynucleotides (ODNs) could specifically activate the human lamina propria B cells to express TLR9 and stimulate immunoglobulin A secretion in the intestine to ameliorate intestinal inflammation (Blaas et al. 2009; Obermeier et al. 2002). Besides, TLR9 has an unexpected pathologic role in some cases. For instance, TLR9-deficient mice represent an advantage to promote the clearance of methicillin-resistant Staphylococcus aureus (MRSA, US300) post the IAV infections, and the lung monocytes/macrophages in $T l r 9^{-/}$mice show increased bacterial phagocytosis and intracellular killing against MRSA (Martínez-Colón et al. 2019).

\section{Bioactive microbial metabolites are crucial signal molecules that modulate the host's immune system}

In addition to microbial components, the bioactive metabolites derived from microbes also contribute to the host's innate and adaptive immunity (Levy et al. 2017; Rooks and Garrett 2016; Shibata et al. 2017). TLRs have emerged as a vital metaboliteimmune axis-mediated factor to affect the host's immune system in some cases. As reported, the intestinal vitamin contents determined by commensal bacteria and diets and VB3 supplementation attenuate TLR2- and TLR4-mediated cytokine release from human monocytes upon stimulation, such as TNF- $\alpha$, IL-6, and monocyte chemotactic protein-1 (MCP-1)
(Digby et al. 2012). Succinate is critical to activate a proinflammatory response in LPS-stimulated cells, and in DCs, GPR91 senses the succinate released from the commensal bacteria, i.e., Prevotella copri, enhancing antigen-specific activation of Th cells and synergizing with TLRs to augment IL$1 \beta$ production (Chen and Stappenbeck 2019; Harber et al. 2020). SCFAs, such as lactate, acetate, propionate, and butyrate, are essential metabolites produced from gut microbial fermentation and play roles in the modulation of TLRmediated pro-inflammatory responses in intestinal epithelial and myeloid cells (Iraporda et al. 2015). For instance, the short incubation of HEK293 or HeLa epithelial cells with butyrate and propionate enhanced NF- $\mathrm{KB}$ activation in response to TLR2/TLR1, TLR4, TLR5, and TLR9 agonists, leading to increased TNF- $\alpha$ transcription and downregulated IL- 8 and MCP-1 expression (Lin et al. 2015; Shibata et al. 2017). Besides, surface polysaccharide A (PSA), the symbiosis factor of Bacteroides fragilis, signals through TLR2 on DCs to promote Th1 cell differentiation and elicit IL-10 production, thereby inhibiting inflammation (Rooks and Garrett 2016; Round et al. 2011; Wang et al. 2006).

\section{Signal pathways activated by TLRs and corresponding ligands}

When microorganisms invade the body, TLRs can recognize and bind to their corresponding ligands, recruit specific adaptors in cells to activate multiple signal pathways, and eliminate microorganisms by stimulating inflammatory responses. The body also has various negative regulatory systems to inhibit the excessive activation of TLR signaling pathways to maintain its immune balance. It has been noted that MyD88, sterile $\alpha$ and armadillo motif-containing protein (SARM), TRIF, and TRIF-related adaptor molecules (TRAMs) act as adaptor proteins to activate two main TLR signaling pathways dependent on MyD88 (Fig. 1) or TRIF (Fig. 2), which mainly induce the expression of inflammatory cytokines or IFNs (Balka and De Nardo 2019; Takeuchi and Akira 2010). SARM is different from other TIR adaptors because it can inhibit the function of TRIF and act as a specific negative regulator for TLR3 and TLR4 signals (Carty et al. 2006).

Upon recognition of the corresponding PAMP, the Cterminal domains of TLRs' ECD are moved closer to each other and dimerize, which leads to the dimerization of the cytoplasmic TIR. The C-terminal TIR domain of MyD88 binds to the cytoplasmic TIR, and the N-terminal death domain is responsible for recruiting interleukin-1 receptor-associated kinase (IRAK) (Yin et al. 2015). It has been reported that MyD88-deficient mice are highly susceptible to Staphylococcus aureus (S. aureus), which may be due to the loss of the ability to recognize many bacterial components in MyD88-deficient mice, such as LPS, peptidoglycans (PGN), 


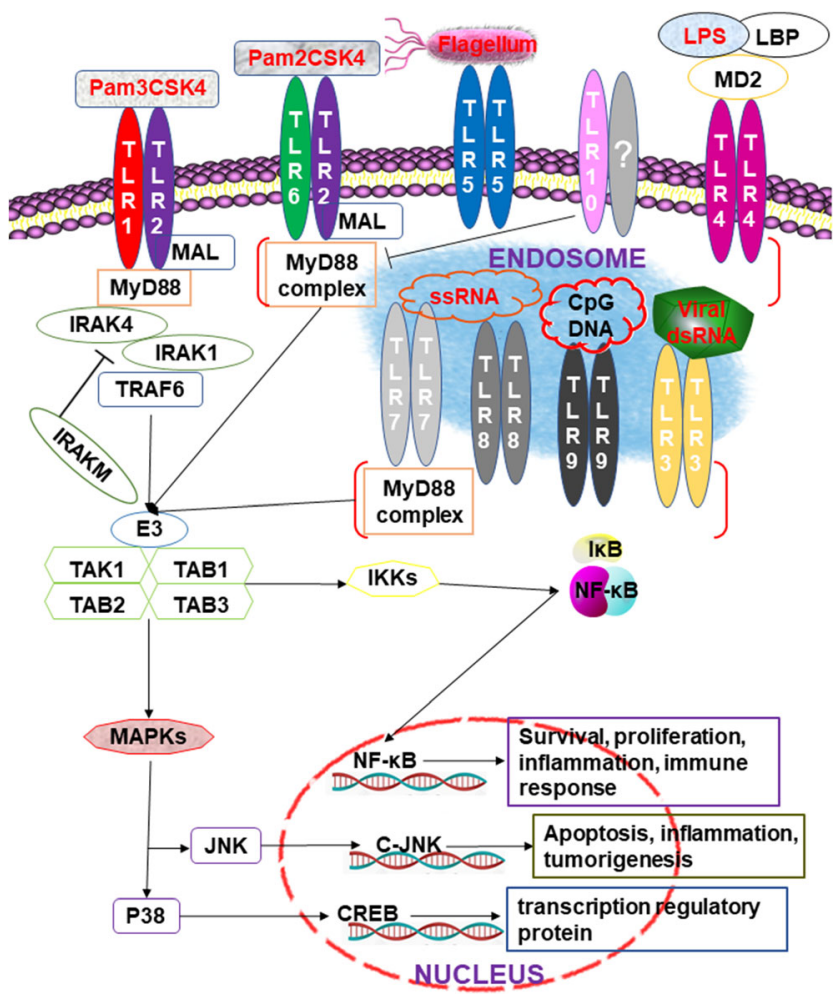

Fig. 1 MyD88-dependent signaling pathways (Takeuchi and Akira 2010; Yin et al. 2015; Zhang and Ghosh 2002). Almost all the TLRs, except TLR3, activate the conserved MyD88-dependent pathway and lead to the activation of NF- $\mathrm{KB}$ and MAP kinases in signal transduction. Upon stimulation with the ligands, the death domain of MyD88 interacts with the cytoplasmic TIR and recruits IRAK-4 to TLRs. After phosphorylation, activated IRAK-1 interacts with TRAF6 and triggers the IKK complex activation and downstream pathways, whereas both TolliP and IRAK-M interact with IRAK-1 and suppress TLR signals

and lipopeptide, along with a reduction in the activation of TLRs and a weaker innate immune response, which is beneficial to the survival of bacteria (Takeuchi et al. 2000). In some cases, the interaction between TLRs and MyD88 also requires the participation of MyD88 adaptor-like (MAL) receptors. For example, TLR9 recognizes the corresponding ligands. It initiates innate immunity against virus infection upon infection with HSV-1, but the deletion of MAL inhibits the activation of TLR9-dependent ERK1/2 and the expression of IFN- $\beta$ and TNF- $\alpha$ (Zyzak et al. 2019).

IRAK also plays a vital role in MyD88-dependent signaling pathways (Fig. 1). The family is mainly composed of four members, namely, IRAK-1, IRAK-2, IRAK-M, and IRAK-4. The MyD88/IRAK4 interaction can promote the phosphorylation of IRAK4, followed by the recruitment and phosphorylation of IRAK1 or IRAK2 (Takeuchi and Akira 2010; Yin et al. 2015). IRAK-M can prevent the dissociation of IRAK1 and IRAK4 from MyD88 or inhibit the phosphorylation of IRAK1 and IRAK4, which plays an inhibitory role in TLR signal pathways. Thus, in the late stage of Leishmania donovani (L. donovani, MHOM/IN/1983/AG83) infection, $L$. donovani can increase IRAK-M expression to inhibit the

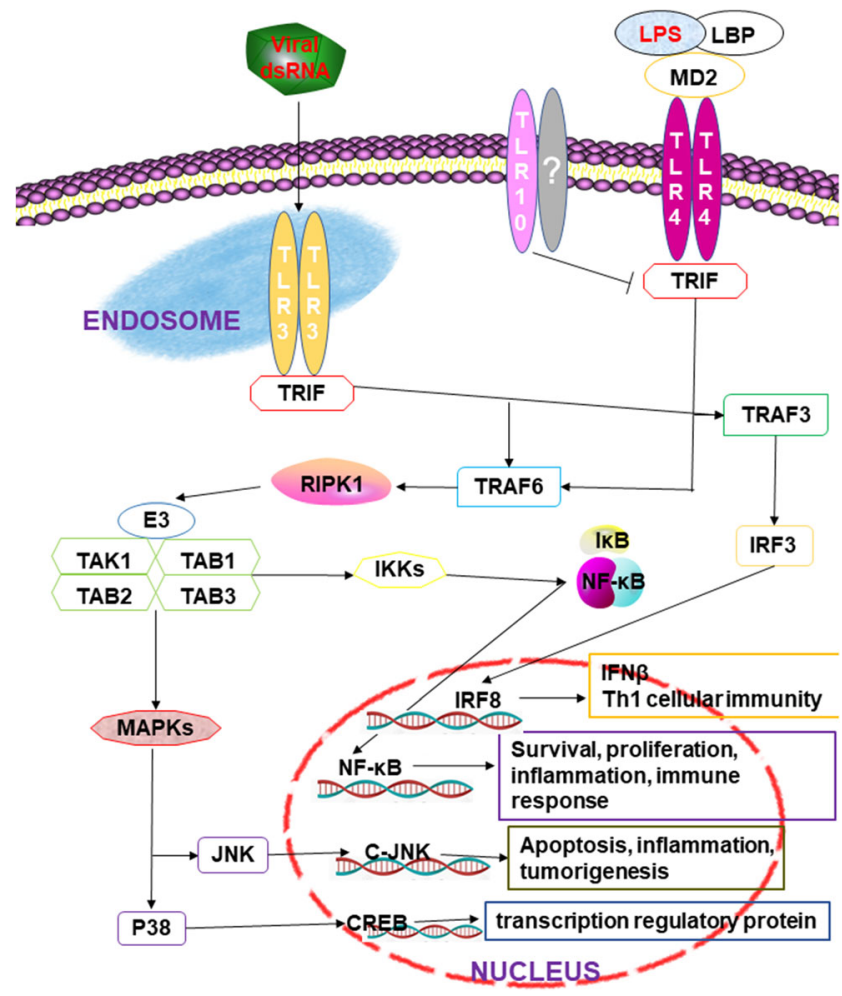

Fig. 2 TRIF-dependent signaling pathways (Cusson-Hermance et al. 2005; Lundberg et al. 2013). MyD88-independent signaling relies on TRIF and is unique to TLR3 and TLR4. TLR3 recognizes dsRNA derived from viruses and plays an important role in the induction of inflammatory cytokines and type I interferons against viral infections. LPS produced by $\mathrm{G}^{-}$bacteria stimulates TLR4 and mediates downstream NF- $\mathrm{KB}$ and MAPK signaling pathways

signal transduction of TLRs in macrophages and then continually infect the host (Srivastav et al. 2015). After a phosphorylated IRAK-1 binds to the C-terminal domain of TNF receptor-associated factor 6 (TRAF6), the IRAK-1/TRAF6 complex dissociates from the receptor and binds to transforming growth factor- $\beta$-activated kinase 1 (TAK1) and TAK-1-binding proteins (TAB), and IRAK-1 stays on the cell membrane and is degraded. In contrast, the TRAF6/TAK1/ $\mathrm{TAB} 1 / \mathrm{TAB} 2 / \mathrm{TAB} 3$ complex enters the cytoplasm and interacts with other proteins, such as ubiquitin ligases (Sharma et al. 2016; Takeuchi and Akira 2010). Pathogenic microorganisms can interact with these signaling factors to evade the host's immunity and establish persistent infection. For example, HCV can induce TRAF6 degradation to inhibit host's innate immune responses (Chan et al. 2016). The $3 \mathrm{C}$ protein of Enterovirus 71 can interact with TAB2 and TAK1 to inhibit the activation of NF-kB (Lei et al. 2014). PtpA, a secreted tyrosine phosphatase of $\mathrm{Mtb}$, can compete with ubiquitin to bind TAB3 to inhibit the production of cytokines in host cells (Wang et al. 2015). The formation of this complex activates IKB kinases (IKK) and JNK, while IKK causes the phosphorylation and degradation of the inhibitor of NF- $\mathrm{KB}(\mathrm{I} \kappa \mathrm{B})$ and the translocation of NF- $\mathrm{KB}$ to the nucleus. Additionally, JNK 
activates AP-1 to mediate the expression of many cytokines and participates in the process of antimicrobial infection (Balka and De Nardo 2019; Mitchell et al. 2016). For example, the porcine reproductive and respiratory syndrome virus (PRRSV) can induce I $\kappa \mathrm{B} \alpha$ protein degradation and activate $\mathrm{NF}-\mathrm{KB}$ in African green monkey embryonic kidney cells. In pulmonary alveolar macrophage, PRRSV induces the degradation of $\operatorname{I\kappa B} \alpha, \operatorname{I\kappa B} \beta$, and $\mathrm{I} \kappa \mathrm{B} \varepsilon$ to activate NF- $\mathrm{BB}$ and induces the expression of IL- 8 through the TAK-1/JNK/AP1 signal pathway, which is beneficial to the body's resistance to PRRSV infection (Cao et al. 2017; Liu et al. 2017). In addition to the above molecules, other molecules are involved in TLR-mediated signaling pathways, such as Toll-interacting protein (Tollip) and E3 ubiquitin ligases, which interact with IRAK-1 and participate in signal transduction (Takeuchi and Akira 2010; Zhang and Ghosh 2002).

TRIF-dependent signaling pathways are unique to some TLRs, such as TLR3 and TLR4 (Fig. 2). TLR3 can be directly combined with TRIF, while TLR4 needs TRAM to promote the combination of TLR4 and TRIF (Lundberg et al. 2013). The binding of TRIF to TLR3 can recruit TRAF3, which is activated by interaction with TRAF family memberassociated NF-KB activators (TANK) and TANK-binding kinase 1 , which leads to the phosphorylation and dimerization of IRF3. Then, IRF3 is transferred to the nucleus to mediate type I interferon gene expression. The results showed that infection with Neospora caninum ( $N$. caninum) could increase the expression of TLR 3 and TRIF in macrophages, inducing nuclear translocation of IRF3, and then increase the expression of IFN- $\alpha$ and IFN- $\beta$ to resist parasite infection. Compared with normal mice, the survival rate of TRIF-deficient mice and the expression of major anti-inflammatory factors such as IL-12, IFN- $\gamma$, and TNF- $\alpha$ decreased after infection with $N$. caninum (Miranda et al. 2019). Decreased expression of TRIF in macrophages can also inhibit TLR4 signaling pathways, such as the cell wall component of Mycobacterium leprae, phenolicglycolipid-1, which can inhibit the function of TLR4 by reducing the expression of TRIF and promoting the survival of Mycobacterium leprosy in the host (Oldenburg et al. 2018).

At the same time, TRIF has a TRAF6-binding motif at its N-terminal domain; TLR3 can recruit TRAF6 after binding with TRIF, while TRAF6 interacts with receptor-interacting protein 1 (RIP1) through its C-terminal RIP homotypic interaction motif and then forms a complex with TAB1, TAB2, and $\mathrm{TAB} 3$ to activate the corresponding signal pathway (Cusson-Hermance et al. 2005). RIP1 is a kinase that plays a key role in the TRIF-dependent signaling pathway; over the process of evolution, some microorganisms produce proteins that can interact with RIP1 to escape the innate immunity of a host. For example, the open reading frame 3 protein produced by hepatitis E virus genotype 1 inhibits the TLR 3 signal pathway by reducing the ubiquitination of RIP1 (He et al. 2016).

\section{The current therapeutic targeting of TLRs in microbial-infected diseases}

TLRs are potential therapeutic targets for many diseases, including allergy, asthma, sepsis, rheumatoid arthritis, inflammatory bowel diseases, and cancers. In the past few years, small molecular compounds, peptide-, protein-, and nucleotide-based antagonists or agonists of TLRs were used to treat diseases or act as vaccine and therapy adjuvants (Hennessy et al. 2010; Uematsu et al. 2004). The development of antagonists and agonists towards TLR2, TLR3, TLR4, TLR5, TLR7, TLR8, and TLR9 showed promising therapeutic effects on bacterial and viral infections (Hennessy et al. 2010; Patel et al. 2014). For instance, the neutralizing monoclonal antibody T2.5 prevents P3CSK 4 or B. subtilis (DSMZ.1087) caused septic shock by blockage of the ligand-TLR2 complex formation (Meng et al. 2004). TLR7activating compounds (APR002) are beneficial to cure HBV in chronic hepatitis B patients (Bertoletti and Le Bert 2019). Another TLR7 agonist, imiquimod (R837), has been approved for use in the treatment of papillomavirus-associated lesions. A recent paper stated that R837 might be helpful to eliminate SARS-CoV-2 during the early phases of infection, depending on its strong immune-boosting and antiviral properties (Poulas et al. 2020). Local vaginal application of $\mathrm{CpG}$ ODNs activates TLR9 signaling to inhibit HSV-2 replication in vaginal epithelial cells and induces an IFN- $\beta$-mediated antiviral protection (Shen and Iwasaki 2006). Besides, the TLR9 agonists MGN1703 is used to augment innate and adaptive antiviral immunity in HIV individuals, enhancing NK and T cell function to boost the clearance of HIV and reducing latency reversal by improving HIV reverse transcription (Offersen et al. 2016; Vibholm et al. 2019). TLR10 depletion through anti-TLR10 antibody blockage and siRNA knockdown is efficient for attenuating gp41-mediated NF- $\mathrm{kB} \alpha$ activation and decreasing HIV-1 infection (Henrick et al. 2019).

\section{Conclusions}

As pattern recognition receptors, TLRs participate in the innate immunity of the body against microbial infections. The study of the interaction between TLRs and their corresponding ligands and the changes of TLR signal molecules during microbial infections helps us clarify the host's immune regulation mechanism and the specific role of related signal molecules in the occurrence and development of diseases. Thus, these signal molecules can be used as ideal targets for preventing and treating microbial diseases. However, the molecular mechanism and the novel therapeutic strategies targeting TLRs to combat microbial infections still need to be elucidated. 
Acknowledgements The authors gratefully acknowledge the language editing service provided by Letpub.

\section{Availability of data and materials Not applicable.}

Code availability Not applicable.

Author contribution PX and GZ participated in the structural design of this paper. PX and YW prepared the figures and drafted the manuscript. SL, LY, XM, QD, and GZ revised the manuscript critically. All authors read and approved the final manuscript.

Funding This study was supported by the Chinese National Science Foundation (Grant No. 32072820, 31702242, 31800121, 31972651), Grant No. 2017YFD0500203 from the National Key Research and Development Program of China, grants from Jiangsu Government Scholarship for Overseas Studies (JS20190246), Jiangsu Planned Projects for Postdoctoral Research Funds (1701053A), a project founded by the Priority Academic Program of Development Jiangsu High Education Institution.

\section{Declarations}

Ethics approval Not applicable.

Consent to participate Not applicable.

Consent for publication All the authors approved and gave their explicit consent for publication of the anuscript.

Conflict of interest The authors declare no competing interests.

\section{References}

Akira S, Uematsu S, Takeuchi O (2006) Pathogen recognition and innate immunity. Cell 124(4):783-801. https://doi.org/10.1016/j.cell.2006. 02.015

Ao D, Xia P, Jiang S, Chen N, Meurens F, Zhu J (2019) Comparative transcriptome analysis of TLR8 signaling cells revealed the porcine TLR8 specific differentially expressed genes. Dev Comp Immunol 98:129-136. https://doi.org/10.1016/j.dci.2019.05.004

Ashkar AA, Mossman KL, Coombes BK, Gyles CL, Mackenzie R (2008) FimH adhesin of type 1 fimbriae is a potent inducer of innate antimicrobial responses which requires TLR4 and type 1 interferon signalling. PLoS Pathog 4(12):e1000233. https://doi.org/10.1371/ journal.ppat.1000233

Balka KR, De Nardo D (2019) Understanding early TLR signaling through the Myddosome. J Leukoc Biol 105(2):339-351. https:// doi.org/10.1002/jlb.mr0318-096r

Basauri A, González-Fernández C, Fallanza M, Bringas E, FernandezLopez R, Giner L, Moncalian G, Cruz F, Ortiz I (2020) Biochemical interactions between LPS and LPS-binding molecules. Crit Rev Biotechnol 40:1-14. https://doi.org/10.1080/07388551.2019. 1709797

Bender AT, Tzvetkov E, Pereira A, Wu Y, Kasar S, Przetak MM, Vlach J, Niewold TB, Jensen MA, Okitsu SL (2020) TLR7 and TLR8 differentially activate the IRF and NF-KB pathways in specific cell types to promote inflammation. Immunohorizons 4(2):93-107. https://doi.org/10.4049/immunohorizons.2000002

Bertoletti A, Le Bert N (2019) Fine-tuning TLR-7-based therapy for functional HBV cure. Hepatol Commun 3(10):1289-1292. https:// doi.org/10.1002/hep4.1420
Bhattarai D, Worku T, Dad R, Rehman ZU, Gong X, Zhang S (2018) Mechanism of pattern recognition receptors (PRRs) and host pathogen interplay in bovine mastitis. Microb Pathog 120:64-70. https:// doi.org/10.1016/j.micpath.2018.04.010

Bianchi F, Alexiadis S, Camisaschi C, Truini M, Centonze G, Milione M, Balsari A, Tagliabue E, Sfondrini L (2020) TLR3 expression induces apoptosis in human non-small-cell lung cancer. Int J Mol Sci 21(4). https://doi.org/10.3390/ijms21041440

Blaas SH, Stieber-Gunckel M, Falk W, Obermeier F, Rogler G (2009) CpG-oligodeoxynucleotides stimulate immunoglobulin A secretion in intestinal mucosal B cells. Clin Exp Immunol 155(3):534-540. https://doi.org/10.1111/j.1365-2249.2008.03855.x

Bonhomme D, Santecchia I, Vernel-Pauillac F, Caroff M, Germon P, Murray G, Adler B, Boneca IG, Werts C (2020) Leptospiral LPS escapes mouse TLR4 internalization and TRIF-associated antimicrobial responses through $\mathrm{O}$ antigen and associated lipoproteins. bioRxiv:2020.05.18.101857. https://doi.org/10.1101/2020.05.18. 101857

Bowie A, O'Neill LA (2000) The interleukin-1 receptor/Toll-like receptor superfamily: signal generators for pro-inflammatory interleukins and microbial products. J Leukoc Biol 67(4):508-514. https://doi. org/10.1002/jlb.67.4.508

Braun V, Hantke K (2019) Lipoproteins: structure, function, biosynthesis. Subcell Biochem 92:39-77. https://doi.org/10.1007/978-3-03018768-2 3

Brencicova E, Diebold S (2013) Nucleic acids and endosomal pattern recognition: how to tell friend from foe? Front Cell Infect Microbiol 3:37. https://doi.org/10.3389/fcimb.2013.00037

Cai J, Xu M, Zhang X, Li H (2019) Innate immune signaling in nonalcoholic fatty liver disease and cardiovascular diseases. Annu Rev Pathol 14:153-184. https://doi.org/10.1146/annurev-pathmechdis012418-013003

Cao L, Chen J, Wei Y, Shi H, Zhang X, Yuan J, Shi D, Liu J, Zhu X, Wang X, Cui S, Feng L (2017) Porcine parvovirus induces activation of NF-KB signaling pathways in PK-15 cells mediated by tolllike receptors. Mol Immunol 85:248-255. https://doi.org/10.1016/j. molimm.2016.12.002

Carty M, Goodbody R, Schröder M, Stack J, Moynagh PN, Bowie AG (2006) The human adaptor SARM negatively regulates adaptor protein TRIF-dependent Toll-like receptor signaling. Nat Immunol 7(10):1074-1081. https://doi.org/10.1038/ni1382

Carty M, Guy C, Bowie AG (2021) Detection of viral infections by innate immunity. Biochem Pharmacol 183:114316. https://doi.org/10. 1016/j.bcp.2020.114316

Chan ST, Lee JY, Narula M, Ou JJ (2016) Suppression of host innate immune response by hepatitis $\mathrm{C}$ virus via induction of autophagic degradation of TRAF6. J Virol 90(23):10928-10935. https://doi. org/10.1128/jvi.01365-16

Chen F, Stappenbeck TS (2019) Microbiome control of innate reactivity. Curr Opin Immunol 56:107-113. https://doi.org/10.1016/j.coi. 2018.12.003

Chen N, Xia P, Li S, Zhang T, Wang TT, Zhu J (2017) RNA sensors of the innate immune system and their detection of pathogens. IUBMB Life 69(5):297-304. https://doi.org/10.1002/iub.1625

Choteau L, Vancraeyneste H, Le Roy D, Dubuquoy L, Romani L, Jouault T, Poulain D, Sendid B, Calandra T, Roger T, Jawhara S (2017) Role of TLR1, TLR2 and TLR6 in the modulation of intestinal inflammation and Candida albicans elimination. Gut Pathog 15;9: 9. https://doi.org/10.1186/s13099-017-0158-0

Ciesielska A, Matyjek M, Kwiatkowska K (2020) TLR4 and CD14 trafficking and its influence on LPS-induced pro-inflammatory signaling. Cell Mol Life Sci 78(4):1233-1261. https://doi.org/10.1007/ s00018-020-03656-y

Conde-Álvarez R, Arce-Gorvel V, Iriarte M, Manček-Keber M, Barquero-Calvo E, Palacios-Chaves L, Chacón-Díaz C, ChavesOlarte E, Martirosyan A, von Bargen K, Grilló MJ, Jerala R, 
Brandenburg K, Llobet E, Bengoechea JA, Moreno E, Moriyón I, Gorvel JP (2012) The lipopolysaccharide core of Brucella abortus acts as a shield against innate immunity recognition. PLoS Pathog 8(5):e1002675. https://doi.org/10.1371/journal.ppat.1002675

Cullender TC, Chassaing B, Janzon A, Kumar K, Muller CE, Werner JJ, Angenent LT, Bell ME, Hay AG, Peterson DA, Walter J, VijayKumar M, Gewirtz AT, Ley RE (2013) Innate and adaptive immunity interact to quench microbiome flagellar motility in the gut. Cell Host Microbe 14(5):571-581. https://doi.org/10.1016/j.chom.2013. 10.009

Cusson-Hermance N, Khurana S, Lee TH, Fitzgerald KA, Kelliher MA (2005) Rip1 mediates the Trif-dependent toll-like receptor 3- and 4induced NF- $\{$ kappa $\}$ B activation but does not contribute to interferon regulatory factor 3 activation. J Biol Chem 280(44):36560 36566. https://doi.org/10.1074/jbc.M506831200

Dai C, Yang L, Jin J, Wang H, Wu S, Bao W (2019) Regulation and molecular mechanism of TLR5 on resistance to Escherichia coli F18 in weaned piglets. Animals 9(10). https://doi.org/10.3390/ ani9100735

Davey M, Liu X, Ukai T, Jain V, Gudino C, Gibson FC 3rd, Golenbock D, Visintin A, Genco CA (2008) Bacterial fimbriae stimulate proinflammatory activation in the endothelium through distinct TLRs. J Immunol 180(4):2187-2195. https://doi.org/10.4049/jimmunol. 180.4.2187

de Marcken M, Dhaliwal K, Danielsen AC, Gautron AS, DominguezVillar M (2019) TLR7 and TLR8 activate distinct pathways in monocytes during RNA virus infection. Sci Signal 12(605): eaaw1347. https://doi.org/10.1126/scisignal.aaw1347

Digby JE, Martinez F, Jefferson A, Ruparelia N, Chai J, Wamil M, Greaves DR, Choudhury RP (2012) Anti-inflammatory effects of nicotinic acid in human monocytes are mediated by GPR109A dependent mechanisms. Arterioscler Thromb Vasc Biol 32(3):669676. https://doi.org/10.1161/atvbaha.111.241836

Duan Q, Zhou M, Zhu X, Bao W, Wu S, Ruan X, Zhang W, Yang Y, Zhu $\mathrm{J}$, Zhu G (2012) The flagella of F18ab Escherichia coli is a virulence factor that contributes to infection in a IPEC-J2 cell model in vitro. Vet Microbiol 160(1-2):132-140. https://doi.org/10.1016/j.vetmic. 2012.05.015

Duan Q, Zhou M, Zhu L, Zhu G (2013) Flagella and bacterial pathogenicity. J Basic Microbiol 53(1):1-8. https://doi.org/10.1002/jobm. 201100335

Fan Y, Yang L, Wei Q, Ding Y, Tang Z, Tan P, Lin T, Guo D, Qiu S (2019) Toll-like receptor 10 (TLR10) exhibits suppressive effects on inflammation of prostate epithelial cells. Asian J Androl 21(4):393399. https://doi.org/10.4103/aja.aja 10018

Farhat K, Riekenberg S, Heine H, Debarry J, Lang R, Mages J, BuwittBeckmann U, Röschmann K, Jung G, Wiesmüller K-H, Ulmer AJ (2008) Heterodimerization of TLR2 with TLR1 or TLR6 expands the ligand spectrum but does not lead to differential signaling. J Leukoc Biol 83(3):692-701. https://doi.org/10.1189/jlb.0807586

Fore F, Indriputri C, Mamutse J, Nugraha J (2020) TLR10 and its unique anti-inflammatory properties and potential use as a target in therapeutics. Immune Netw 20(3):e21. https://doi.org/10.4110/in.2020. 20.e21

Frendéus B, Wachtler C, Hedlund M, Fischer H, Samuelsson P, Svensson M, Svanborg C (2001) Escherichia coli P fimbriae utilize the Tolllike receptor 4 pathway for cell activation. Mol Microbiol 40(1):3751. https://doi.org/10.1046/j.1365-2958.2001.02361.x

Gantier MP, Irving AT, Kaparakis-Liaskos M, Xu D, Evans VA, Cameron PU, Bourne JA, Ferrero RL, John M, Behlke MA, Williams BR (2010) Genetic modulation of TLR8 response following bacterial phagocytosis. Hum Mutat 31(9):1069-1079. https:// doi.org/10.1002/humu.21321

Gegner JA, Ulevitch RJ, Tobias PS (1995) Lipopolysaccharide (LPS) signal transduction and clearance. Dual roles for LPS binding protein and membrane CD14. J Biol Chem 270(10):5320-5325. https://doi.org/10.1074/jbc.270.10.5320

Gosu V, Son S, Shin D, Song K-D (2019) Insights into the dynamic nature of the dsRNA-bound TLR3 complex. Sci Rep 9(1):3652. https://doi.org/10.1038/s41598-019-39984-8

Hajam IA, Dar PA, Shahnawaz I, Jaume JC, Lee JH (2017) Bacterial flagellin-a potent immunomodulatory agent. Exp Mol Med 49(9): e373. https://doi.org/10.1038/emm.2017.172

Harber KJ, de Goede KE, Verberk SGS, Meinster E, de Vries HE, van Weeghel M, de Winther MPJ, Van den Bossche J (2020) Succinate is an inflammation-induced immunoregulatory metabolite in macrophages. Metabolites 10(9). https://doi.org/10.3390/ metabo 10090372

Hashimoto M, Tawaratsumida K, Kariya H, Aoyama K, Tamura T, Suda Y (2006) Lipoprotein is a predominant Toll-like receptor 2 ligand in Staphylococcus aureus cell wall components. Int Immunol 18(2): 355-362. https://doi.org/10.1093/intimm/dxh374

He Y, Xu T, Fossheim LE, Zhang XH (2012) FliC, a flagellin protein, is essential for the growth and virulence of fish pathogen Edwardsiella tarda. PLoS One 7(9):e45070. https://doi.org/10.1371/journal.pone. 0045070

He M, Wang M, Huang Y, Peng WJ, Zheng ZZ, Xia NS, Xu J, Tian DY (2016) The ORF3 protein of genotype 1 Hepatitis E virus suppresses TLR3-induced NF-kB signaling via TRADD and RIP1. Sci Rep 6: 27597. https://doi.org/10.1038/srep27597

Hennessy EJ, Parker AE, O'Neill LAJ (2010) Targeting Toll-like receptors: emerging therapeutics? Nat Rev Drug Discov 9(4):293-307. https://doi.org/10.1038/nrd3203

Henrick BM, Yao XD, Zahoor MA, Abimiku A, Osawe S, Rosenthal KL (2019) TLR10 senses HIV-1 proteins and significantly enhances HIV-1 infection. Front Immunol 10:482. https://doi.org/10.3389/ fimmu.2019.00482

Hess NJ, Jiang S, Li X, Guan Y, Tapping RI (2017) TLR10 is a B cell intrinsic suppressor of adaptive immune responses. J Immunol 198(2):699-707. https://doi.org/10.4049/jimmunol.1601335

Iraporda C, Errea A, Romanin DE, Cayet D, Pereyra E, Pignataro O, Sirard JC, Garrote GL, Abraham AG, Rumbo M (2015) Lactate and short chain fatty acids produced by microbial fermentation downregulate proinflammatory responses in intestinal epithelial cells and myeloid cells. Immunobiology 220(10):1161-1169. https://doi.org/10.1016/j.imbio.2015.06.004

Jerala R (2007) Structural biology of the LPS recognition. Int J Med Microbiol 297(5):353-363. https://doi.org/10.1016/j.ijmm.2007. 04.001

Jiang S, Li X, Hess NJ, Guan Y, Tapping RI (2016) TLR10 is a negative regulator of both MyD88-dependent and -independent TLR signaling. J Immunol 196(9):3834-3841. https://doi.org/10.4049/ jimmunol.1502599

Jin MS, Kim SE, Heo JY, Lee ME, Kim HM, Paik SG, Lee H, Lee JO (2007) Crystal structure of the TLR1-TLR2 heterodimer induced by binding of a tri-acylated lipopeptide. Cell 130(6):1071-1082. https://doi.org/10.1016/j.cell.2007.09.008

Kant R, de Vos WM, Palva A, Satokari R (2014) Immunostimulatory $\mathrm{CpG}$ motifs in the genomes of gut bacteria and their role in human health and disease. J Med Microbiol 63(Pt 2):293-308. https://doi. org/10.1099/jmm.0.064220-0

Kawai T, Akira S (2007) Signaling to NF-kB by Toll-like receptors. Trends Mol Med 13(11):460-469. https://doi.org/10.1016/j. molmed.2007.09.002

Kayama H, Okumura R, Takeda K (2020) Interaction between the microbiota, epithelia, and immune cells in the intestine. Annu Rev Immunol 38:23-48. https://doi.org/10.1146/annurev-immunol070119-115104

Kitchens RL, Thompson PA (2005) Modulatory effects of sCD14 and LBP on LPS-host cell interactions. J Endotoxin Res 11(4):225-229. https://doi.org/10.1179/096805105x46565 
Lai JH, Wang MY, Huang CY, Wu CH, Hung LF, Yang CY, Ke PY, Luo SF, Liu SJ, Ho LJ (2018) Infection with the dengue RNA virus activates TLR9 signaling in human dendritic cells. EMBO Rep 19(8):e46182. https://doi.org/10.15252/embr.201846182

Langston PK, Nambu A, Jung J, Shibata M, Aksoylar HI, Lei J, Xu P, Doan MT, Jiang H, MacArthur MR, Gao X, Kong Y, Chouchani ET, Locasale JW, Snyder NW, Horng T (2019) Glycerol phosphate shuttle enzyme GPD2 regulates macrophage inflammatory responses. Nat Immunol 20(9):1186-1195. https://doi.org/10.1038/ s41590-019-0453-7

Latorre E, Pradilla A, Chueca B, Pagán R, Layunta E, Alcalde AI, Mesonero JE (2016) Listeria monocytogenes inhibits serotonin transporter in human intestinal Caco-2 cells. Microb Ecol 72(3): 730-739. https://doi.org/10.1007/s00248-016-0809-6

Lawrence T (2009) The nuclear factor NF-kappaB pathway in inflammation. Cold Spring Harb Perspect Biol 1(6):a001651. https://doi.org/ 10.1101/cshperspect.a001651

Le Goffic R, Balloy V, Lagranderie M, Alexopoulou L, Escriou N, Flavell R, Chignard M, Si-Tahar M (2006) Detrimental contribution of the Toll-like receptor (TLR)3 to influenza A virus-induced acute pneumonia. PLoS Pathog 2(6):e53. https://doi.org/10.1371/journal. ppat.0020053

Lebeer S, Vanderleyden J, De Keersmaecker SCJ (2010) Host interactions of probiotic bacterial surface molecules: comparison with commensals and pathogens. Nat Rev Microbiol 8(3):171-184. https:// doi.org/10.1038/nrmicro2297

Lee BL, Barton GM (2014) Trafficking of endosomal Toll-like receptors. Trends Cell Biol 24(6):360-369. https://doi.org/10.1016/j.tcb.2013. 12.002

Lee S, Kang D, Ra EA, Lee TA, Ploegh HL, Park B (2014a) Negative self-regulation of TLR9 signaling by its N-terminal proteolytic cleavage product. J Immunol 193(7):3726-3735. https://doi.org/ 10.4049/jimmunol.1400210

Lee SM, Kok KH, Jaume M, Cheung TK, Yip TF, Lai JC, Guan Y, Webster RG, Jin DY, Peiris JS (2014b) Toll-like receptor 10 is involved in induction of innate immune responses to influenza virus infection. Proc Natl Acad Sci U S A 111(10):3793-3798. https://doi. org/10.1073/pnas.1324266111

Lei XB, Han N, Xiao X, Jin Q, He B, Wang JW (2014) Enterovirus 71 3C inhibits cytokine expression through cleavage of the TAK1/TAB1/ TAB2/TAB3 complex. J Virol 88(17):9830-9841. https://doi.org/ 10.1128/jvi.01425-14

Lester SN, Li K (2014) Toll-like receptors in antiviral innate immunity. J Mol Biol 426(6):1246-1264. https://doi.org/10.1016/j.jmb.2013.11. 024

Levy M, Blacher E, Elinav E (2017) Microbiome, metabolites and host immunity. Curr Opin Microbiol 35:8-15. https://doi.org/10.1016/j. mib.2016.10.003

Li Y, Powell DA, Shaffer SA, Rasko DA, Pelletier MR, Leszyk JD, Scott AJ, Masoudi A, Goodlett DR, Wang X, Raetz CR, Ernst RK (2012) LPS remodeling is an evolved survival strategy for bacteria. Proc Natl Acad Sci U S A 109(22):8716-8721. https://doi.org/10.1073/ pnas.1202908109

Liang Y, Cao X, Ding Q, Zhao Y, He Z, Zhong J (2018) Hepatitis C virus NS4B induces the degradation of TRIF to inhibit TLR3-mediated interferon signaling pathway. PLoS Pathog 14(5):e1007075e1007075. https://doi.org/10.1371/journal.ppat.1007075

Lin MY, de Zoete MR, van Putten JP, Strijbis K (2015) Redirection of epithelial immune responses by short-chain fatty acids through inhibition of histone deacetylases. Front Immunol 6:554. https://doi. org/10.3389/fimmu.2015.00554

Ling GS, Bennett J, Woollard KJ, Szajna M, Fossati-Jimack L, Taylor PR, Scott D, Franzoso G, Cook HT, Botto M (2014) Integrin CD11b positively regulates TLR4-induced signalling pathways in dendritic cells but not in macrophages. Nat Commun 5(1):3039. https://doi. org/10.1038/ncomms4039
Ling N, Wang X, Liu D, Shen Y, Zhang D, Ou D, Fan H, Wang J, Ding Y, Zhang J, Wu Q, Ye Y (2021) Role of fliC on biofilm formation, adhesion, and cell motility in Cronobacter malonaticus and regulation of luxS. Food Chem Toxicol 149:111940. https://doi.org/10. 1016/j.fct.2020.111940

Liu L, Botos I, Wang Y, Leonard JN, Shiloach J, Segal DM, Davies DR (2008) Structural basis of toll-like receptor 3 signaling with doublestranded RNA. Science 320(5874):379-381. https://doi.org/10. 1126/science. 1155406

Liu Y, Du Y, Wang H, Du L, Feng WH (2017) Porcine reproductive and respiratory syndrome virus (PRRSV) up-regulates IL-8 expression through TAK-1/JNK/AP-1 pathways. Virology 506:64-72. https:// doi.org/10.1016/j.virol.2017.03.009

Lundberg AM, Ketelhuth DFJ, Johansson ME, Gerdes N, Liu S, Yamamoto M, Akira S, Hansson GK (2013) Toll-like receptor 3 and 4 signalling through the TRIF and TRAM adaptors in haematopoietic cells promotes atherosclerosis. Cardiovasc Res 99(2):364-373. https://doi.org/10.1093/cvr/cvt033

Luo Y, Xu J, Zhang C, Jiang C, Ma Y, He H, Wu Y, Devriendt B, Cox E, Zhang H (2019) Toll-like receptor 5-mediated IL-17C expression in intestinal epithelial cells enhances epithelial host defense against $\mathrm{F}^{+}$ETEC infection. Vet Res 50(1):48. https://doi.org/10.1186/ s13567-019-0665-8

Maeda K, Akira S (2016) TLR7 structure: cut in Z-Loop. Immunity 45(4):705-707. https://doi.org/10.1016/j.immuni.2016.10.003

Malik YS, Sircar S, Bhat S, Sharun K, Dhama K, Dadar M, Tiwari R, Chaicumpa W (2020) Emerging novel coronavirus (2019-nCoV)current scenario, evolutionary perspective based on genome analysis and recent developments. Vet Q 40(1):68-76. https://doi.org/10. 1080/01652176.2020.1727993

Martínez-Colón GJ, Warheit-Niemi H, Gurczynski SJ, Taylor QM, Wilke CA, Podsiad AB, Crespo J, Bhan U, Moore BB (2019) Influenza-induced immune suppression to methicillin-resistant Staphylococcus aureus is mediated by TLR9. PLoS Pathog 15(1): e1007560. https://doi.org/10.1371/journal.ppat.1007560

Massari P, Visintin A, Gunawardana J, Halmen KA, King CA, Golenbock DT, Wetzler LM (2006) Meningococcal porin PorB binds to TLR2 and requires TLR1 for signaling. J Immunol 176(4):2373-80. https://doi.org/10.4049/jimmunol.176.4.2373

Mazgaeen L, Gurung P (2020) Recent advances in lipopolysaccharide recognition systems. Int J Mol Sci 21(2). https://doi.org/10.3390/ ijms 21020379

Meng G, Rutz M, Schiemann M, Metzger J, Grabiec A, Schwandner R, Luppa PB, Ebel F, Busch DH, Bauer S, Wagner H, Kirschning CJ (2004) Antagonistic antibody prevents toll-like receptor 2-driven lethal shock-like syndromes. J Clin Invest 113(10):1473-1481. https://doi.org/10.1172/jci20762

Miao EA, Alpuche-Aranda CM, Dors M, Clark AE, Bader MW, Miller SI, Aderem A (2006) Cytoplasmic flagellin activates caspase-1 and secretion of interleukin 1beta via Ipaf. Nat Immunol 7(6):569-575. https://doi.org/10.1038/ni1344

Miranda VDS, França FBF, da Costa MS, Silva VRS, Mota CM, Barros P, Parreira KS, Santiago FM, Mineo JR, Mineo TWP (2019) TollLike receptor 3-TRIF pathway activation by Neospora caninum RNA enhances infection control in mice. Infect Immun 87(4). https://doi.org/10.1128/iai.00739-18

Mitchell S, Vargas J, Hoffmann A (2016) Signaling via the NFKB system. Wiley Interdiscip Rev Syst Biol Med 8(3):227-241. https://doi. org/10.1002/wsbm.1331

Mukherjee S, Karmakar S, Babu SPS (2016) TLR2 and TLR4 mediated host immune responses in major infectious diseases: a review. Braz J Infect Dis 20(2):193-204. https://doi.org/10.1016/j.bjid.2015.10. 011

Nagaoka K, Takahara K, Tanaka K, Yoshida H, Steinman RM, Saitoh S, Akashi-Takamura S, Miyake K, Kang YS, Park CG, Inaba K (2005) Association of SIGNR1 with TLR4-MD-2 enhances signal 
transduction by recognition of LPS in gram-negative bacteria. Int Immunol 17(7):827-836. https://doi.org/10.1093/intimm/dxh264

Nanziri C, Ario AR, Ntono V, Monje F, Aliddeki DM, Bainomugisha K, Kadobera D, Bulage L, Nsereko G, Kayiwa J, Nakiire L, Walwema R, Tusiime PK, Mabumba E, Makumbi I, Ocom F, Lamorde M, Kasule JN, Ward SE, Merrill RD (2020) Ebola virus disease preparedness assessment and risk mapping in Uganda, AugustSeptember 2018. Health Secur 18(2):105-113. https://doi.org/10. 1089/hs.2019.0118

Needham BD, Trent MS (2013) Fortifying the barrier: the impact of lipid A remodelling on bacterial pathogenesis. Nat Rev Microbiol 11(7): 467-481. https://doi.org/10.1038/nrmicro3047

Netea MG, van der Graaf C, Van der Meer JW, Kullberg BJ (2004a) Tolllike receptors and the host defense against microbial pathogens: bringing specificity to the innate-immune system. J Leukoc Biol 75(5):749-755. https://doi.org/10.1189/jlb.1103543

Netea MG, Van der Meer JW, Kullberg BJ (2004b) Toll-like receptors as an escape mechanism from the host defense. Trends Microbiol 12(11):484-488. https://doi.org/10.1016/j.tim.2004.09.004

Nguyen M-T, Götz F (2016) Lipoproteins of gram-positive bacteria: key players in the immune response and virulence. Microbiol Mol Biol Rev 80:891-903. https://doi.org/10.1128/MMBR.00028-16

Obermeier F, Dunger N, Deml L, Herfarth H, Schölmerich J, Falk W (2002) CpG motifs of bacterial DNA exacerbate colitis of dextran sulfate sodium-treated mice. Eur J Immunol 32(7):2084-2092

Offersen R, Nissen SK, Rasmussen TA, Østergaard L, Denton PW, Søgaard OS, Tolstrup M (2016) A novel Toll-Like receptor 9 agonist, MGN1703, enhances HIV-1 transcription and NK cellmediated inhibition of HIV-1-infected autologous $\mathrm{CD} 4^{+} \mathrm{T}$ cells. J Virol 90(9):4441-4453. https://doi.org/10.1128/jvi.00222-16

Ohto U, Tanji H, Shimizu T (2014) Structure and function of toll-like receptor 8. Microbes Infect 16(4):273-282. https://doi.org/10.1016/ j.micinf.2014.01.007

Ohto U, Shibata T, Tanji H, Ishida H, Krayukhina E, Uchiyama S, Miyake K, Shimizu T (2015) Structural basis of CpG and inhibitory DNA recognition by Toll-like receptor 9. Nature 520(7549):702705. https://doi.org/10.1038/nature14138

Oldenburg R, Mayau V, Prandi J, Arbues A, Astarie-Dequeker C, Guilhot C, Werts C, Winter N, Demangel C (2018) Mycobacterial phenolic glycolipids selectively disable TRIF-dependent TLR4 signaling in macrophages. Front Immunol 9:2. https://doi.org/10.3389/ fimmu.2018.00002

Oliveira-Nascimento L, Massari P, Wetzler LM (2012) The role of TLR2 in infection and immunity. Front Immunol 3:79. https://doi.org/10. 3389/fimmu.2012.00079

Oosting M, Cheng S-C, Bolscher JM, Vestering-Stenger R, Plantinga TS, Verschueren IC, Arts P, Garritsen A, van Eenennaam H, Sturm P, Kullberg B-J, Hoischen A, Adema GJ, van der Meer JWM, Netea MG, Joosten LAB (2014) Human TLR10 is an anti-inflammatory pattern-recognition receptor. Proc Natl Acad Sci U S A 111(42): E4478-E4484. https://doi.org/10.1073/pnas.1410293111

Pachathundikandi SK, Tegtmeyer N, Arnold I, Lind J, Neddermann M, Falkeis-Veits C, Chattopadhyay S, Brönstrup M, Tegge W, Hong M, Sticht H, Vieth M, Müller A, Backert S (2019) T4SS-dependent TLR5 activation by Helicobacter pylori infection. Nat Commun 10: 5717. https://doi.org/10.1038/s41467-019-13506-6

Padhi A, Pattnaik K, Biswas M, Jagadeb M, Behera A, Sonawane A (2019) Mycobacterium tuberculosis LprE suppresses TLR2dependent cathelicidin and autophagy expression to enhance bacterial survival in macrophages. J Immunol 203(10):2665-2678. https://doi.org/10.4049/jimmunol.1801301

Patel MC, Shirey KA, Pletneva LM, Boukhvalova MS, Garzino-Demo A, Vogel SN, Blanco JC (2014) Novel drugs targeting Toll-like receptors for antiviral therapy. Futur Virol 9(9):811-829. https:// doi.org/10.2217/fvl.14.70
Pennini M, Pai R, Schultz D, Boom W, Harding C (2006) Mycobacterium tuberculosis 19-kDa lipoprotein inhibits IFNgamma-induced chromatin remodeling of MHC2TA by TLR2 and MAPK signaling. J Immunol 176:4323-4330. https://doi.org/10. 4049/jimmunol.176.7.4323

Poulas K, Farsalinos K, Zanidis C (2020) Activation of TLR7 and innate immunity as an efficient method against COVID-19 pandemic: imiquimod as a potential therapy. Front Immunol 11:1373. https:// doi.org/10.3389/fimmu.2020.01373

Raieli S, Trichot C, Korniotis S, Pattarini L, Soumelis V (2019) TLR1/2 orchestrate human plasmacytoid predendritic cell response to gram ${ }^{+}$ bacteria. PLoS Biol 17(4):e3000209-e3000209. https://doi.org/10. 1371/journal.pbio.3000209

Ramos HC, Rumbo M, Sirard J-C (2004) Bacterial flagellins: mediators of pathogenicity and host immune responses in mucosa. Trends Microbiol 12(11):509-517. https://doi.org/10.1016/j.tim.2004.09. 002

Regan T, Nally K, Carmody R, Houston A, Shanahan F, MacSharry J, Brint E (2013) Identification of TLR10 as a key mediator of the inflammatory response to Listeria monocytogenes in intestinal epithelial cells and macrophages. J Immunol 191(12):6084-6092. https://doi.org/10.4049/jimmunol.1203245

Richter JM, Schanbacher BL, Huang H, Xue J, Bauer JA, Giannone PJ (2012) LPS-binding protein enables intestinal epithelial restitution despite LPS exposure. J Pediatr Gastroenterol Nutr 54(5):639-644. https://doi.org/10.1097/MPG.0b013e31823a895a

Rietschel ET, Kirikae T, Schade FU, Mamat U, Schmidt G, Loppnow H, Ulmer AJ, Zähringer U, Seydel U, Di Padova F, Schreier M, Brade $H$ (1994) Bacterial endotoxin: molecular relationships of structure to activity and function. FASEB J 8(2):217-225. https://doi.org/10. 1096/fasebj.8.2.8119492

Rooks MG, Garrett WS (2016) Gut microbiota, metabolites and host immunity. Nat Rev Immunol 16(6):341-352. https://doi.org/10. 1038/nri.2016.42

Rosadini CV, Kagan JC (2017) Early innate immune responses to bacterial LPS. Curr Opin Immunol 44:14-19. https://doi.org/10.1016/j. coi.2016.10.005

Rossez Y, Wolfson EB, Holmes A, Gally DL, Holden NJ (2015) Bacterial flagella: twist and stick, or dodge across the kingdoms. PLoS Pathog 11(1):e1004483. https://doi.org/10.1371/journal.ppat. 1004483

Round JL, Lee SM, Li J, Tran G, Jabri B, Chatila TA, Mazmanian SK (2011) The Toll-Like receptor 2 pathway establishes colonization by a commensal of the human microbiota. Science 332(6032):974977. https://doi.org/10.1126/science.1206095

Rumbo M, Carnoy C, Sirard JC (2017) Chapter 7 - Flagellins as adjuvants of vaccines. In: VEJC S, O'Hagan DT (eds) Immunopotentiators in modern vaccines, 2nd edn. Academic Press, pp 129-147. https://doi. org/10.1016/B978-0-12-804019-5.00007-4

Schlee M, Wehkamp J, Altenhoefer A, Oelschlaeger TA, Stange EF, Fellermann K (2007) Induction of human $\beta$-defensin 2 by the probiotic Escherichia coli Nissle 1917 is mediated through flagellin. Infect Immun 75(5):2399-2407. https://doi.org/10.1128/iai.0156306

Sharma S, Garg I, Ashraf MZ (2016) TLR signalling and association of TLR polymorphism with cardiovascular diseases. Vasc Pharmacol 87:30-37. https://doi.org/10.1016/j.vph.2016.10.008

Shen H, Iwasaki A (2006) A crucial role for plasmacytoid dendritic cells in antiviral protection by $\mathrm{CpG}$ ODN-based vaginal microbicide. $\mathrm{J}$ Clin Invest 116(8):2237-2243. https://doi.org/10.1172/jci28681

Shibata N, Kunisawa J, Kiyono H (2017) Dietary and microbial metabolites in the regulation of host immunity. Front Microbiol 7(8):2171. https://doi.org/10.3389/fmicb.2017.02171

Shin D-M, Yuk J-M, Lee H-M, Lee S-H, Son JW, Harding CV, Kim J-M, Modlin RL, Jo E-K (2010) Mycobacterial lipoprotein activates autophagy via TLR2/1/CD14 and a functional vitamin D receptor 
signalling. Cell Microbiol 12(11):1648-1665. https://doi.org/10. 1111/j.1462-5822.2010.01497.x

Song W, Jeon Y, Namgung B, Hong M, Yoon S (2017) A conserved TLR5 binding and activation hot spot on flagellin. Sci Rep 7:40878. https://doi.org/10.1038/srep40878

Srivastav S, Saha A, Baru J, Ukil A, Das PK (2015) IRAK-M regulates the inhibition of TLR-mediated macrophage immune response during late in vitro Leishmania donovani infection. Eur J Immunol 45(10):2787-2797. https://doi.org/10.1002/eji.201445336

Su S-B, Tao L, Deng Z-P, Chen W, Qin S-Y, Jiang H-X (2020) TLR10: Insights, controversies and potential utility as a therapeutic target. Scand J Immunol 12:e12988. https://doi.org/10.1111/sji.12988

Sutcliffe IC, Harrington DJ (2004) Lipoproteins of Mycobacterium tuberculosis: an abundant and functionally diverse class of cell envelope components. FEMS Microbiol Rev 28(5):645-659. https:// doi.org/10.1016/j.femsre.2004.06.002

Takeuchi O, Akira S (2010) Pattern recognition receptors and inflammation. Cell 140(6):805-820. https://doi.org/10.1016/j.cell.2010.01. 022

Takeuchi O, Hoshino K, Akira S (2000) Cutting edge: TLR2-deficient and MyD88-deficient mice are highly susceptible to Staphylococcus aureus infection. J Immunoass 165(10):5392-5396. https://doi.org/ 10.4049/jimmunol.165.10.5392

Tanji H, Ohto U, Shibata T, Taoka M, Yamauchi Y, Isobe T, Miyake K, Shimizu T (2015) Toll-like receptor 8 senses degradation products of single-stranded RNA. Nat Struct Mol Biol 22(2):109-115. https:// doi.org/10.1038/nsmb.2943

Tasiame W, Johnson S, Burimuah V, Akyereko E, El-Duah P, Amemor E, Emikpe BO, Owiredu EW (2020) Outbreak of highly pathogenic avian influenza in Ghana, 2015: degree of losses and outcomes of time-course outbreak management. Epidemiol Infect 148:e45. https://doi.org/10.1017/s095026882000045x

Triantafilou M, Gamper FG, Haston RM, Mouratis MA, Morath S, Hartung T, Triantafilou K (2006) Membrane sorting of toll-like receptor (TLR)-2/6 and TLR2/1 heterodimers at the cell surface determines heterotypic associations with CD36 and intracellular targeting. J Biol Chem 281(41):31002-31011. https://doi.org/10. 1074/jbc.M602794200

Uematsu S, Ishii KJ, Akira S (2004) Therapeutic targeting of Toll-like receptors. Drug Discov Today 1(3):299-304. https://doi.org/10. 1016/j.ddstr.2004.10.009

Vibholm LK, Konrad CV, Schleimann MH, Frattari G, Winckelmann A, Klastrup V, Jensen NM, Jensen SS, Schmidt M, Wittig B, Zuwala K, Mack K, Olesen R, Hua S, Lichterfeld M, Østergaard L, Denton PW, Tolstrup M, Søgaard OS (2019) Effects of 24-week Toll-like receptor 9 agonist treatment in HIV type $1^{+}$individuals. AIDS 33(8): 1315-1325. https://doi.org/10.1097/qad.0000000000002213

Wagner H (2004) The immunobiology of the TLR9 subfamily. Trends Immunol 25(7):381-386. https://doi.org/10.1016/j.it.2004.04.011

Wang Q, McLoughlin RM, Cobb BA, Charrel-Dennis M, Zaleski KJ, Golenbock D, Tzianabos AO, Kasper DL (2006) A bacterial carbohydrate links innate and adaptive responses through toll-like receptor 2. J Exp Med 203(13):2853-2863. https://doi.org/10.1084/jem. 20062008

Wang J, Li BX, Ge PP, Li J, Wang Q, Gao GF, Qiu XB, Liu CH (2015) Mycobacterium tuberculosis suppresses innate immunity by coopting the host ubiquitin system. Nat Immunol 16(3):237-245. https://doi.org/10.1038/ni.3096
Wang RN, Zhang Y, Cao ZH, Wang XY, Ma B, Wu WB, Hu N, Huo ZY, Yuan QB (2019) Occurrence of super antibiotic resistance genes in the downstream of the Yangtze River in China: prevalence and antibiotic resistance profiles. Sci Total Environ 651:1946-1957. https://doi.org/10.1016/j.scitotenv.2018.10.111

Xiang Q, Zhu L, Zheng K, Ding Y, Chen N, Liu G, He Q (2020) Association of toll-like receptor 10 polymorphisms with pediatric pneumococcal meningitis. APMIS 128(4):335-342. https://doi.org/ 10.1111/apm. 13028

Xu M, Xie Y, Tan M, Zheng K, Xiao Y, Jiang C, Zhao F, Zeng T, Wu Y (2019) The N-terminal D1 domain of Treponema pallidum flagellin binding to TLR5 is required but not sufficient in activation of TLR5. J Cell Mol Med 23(11):7490-7504. https://doi.org/10.1111/jcmm. 14617

Yang J, Zhao Y, Shao F (2015) Non-canonical activation of inflammatory caspases by cytosolic LPS in innate immunity. Curr Opin Immunol 32:78-83. https://doi.org/10.1016/j.coi.2015.01.007

Yang Y, Yang Y, Ou B, Xia P, Zhou M, Li L, Zhu G (2016) The flagellin hypervariable region is a potential flagella display domain in probiotic Escherichia coli strain Nissle 1917. Arch Microbiol 198(7): 603-610. https://doi.org/10.1007/s00203-016-1219-3

Yi Y-S (2017) Caspase-11 non-canonical inflammasome: a critical sensor of intracellular lipopolysaccharide in macrophage-mediated inflammatory responses. Immunology 152(2):207-217. https://doi.org/10. 1111/imm.12787

Yin Q, Fu TM, Li J, Wu H (2015) Structural biology of innate immunity. Annu Rev Immunol 33:393-416. https://doi.org/10.1146/annurevimmunol-032414-112258

Yoon S, Kurnasov O, Natarajan V, Hong M, Gudkov A, Osterman A, Wilson I (2012) Structural basis of TLR5-flagellin recognition and signaling. Science 335:859-864. https://doi.org/10.1126/science. 1215584

Zang R, Lian H, Zhong X, Yang Q, Shu HB (2020) ZCCHC3 modulates TLR3-mediated signaling by promoting recruitment of TRIF to TLR3. J Mol Cell Biol 12(4):251-262. https://doi.org/10.1093/ jmcb/mjaa004

Zhang G, Ghosh S (2002) Negative regulation of Toll-like receptor-mediated signaling by Tollip. J Biol Chem 277(9):7059-7065. https:// doi.org/10.1074/jbc.M109537200

Zhang Z, Ohto U, Shibata T, Krayukhina E, Taoka M, Yamauchi Y, Tanji $\mathrm{H}$, Isobe T, Uchiyama S, Miyake K, Shimizu T (2016) Structural analysis reveals that Toll-like receptor 7 is a dual receptor for guanosine and single-stranded RNA. Immunity 45(4):737-748. https:// doi.org/10.1016/j.immuni.2016.09.011

Zhang Z, Ohto U, Shibata T, Taoka M, Yamauchi Y, Sato R, Shukla NM, David SA, Isobe T, Miyake K, Shimizu T (2018) Structural analyses of Toll-like receptor 7 reveal detailed RNA sequence specificity and recognition mechanism of agonistic ligands. Cell Rep 25(12):33713381.e5. https://doi.org/10.1016/j.celrep.2018.11.081

Zyzak J, Mitkiewicz M, Leszczyńska E, Reniewicz P, Moynagh PN, Siednienko J (2019) HSV-1/TLR9-Mediated IFN $\beta$ and TNF $\alpha$ induction is Mal-dependent in macrophages. J Innate Immun 12(5): 387-398. https://doi.org/10.1159/000504542

Publisher's note Springer Nature remains neutral with regard to jurisdictional claims in published maps and institutional affiliations. 